2013s-23

\title{
Trend-Cycle Decomposition: Implications from an Exact Structural Identification
}

Mardi Dungey, Jan P.A.M. Jacobs, Jing Tian, Simon van Norden

\begin{tabular}{c}
\hline $\begin{array}{c}\text { Série Scientifique } \\
\text { Scientific Series }\end{array}$ \\
\hline
\end{tabular}

Montréal

Juillet 2013

(C) 2013 Mardi Dungey, Jan P.A.M. Jacobs, Jing Tian, Simon van Norden. Tous droits réservés. All rights reserved. Reproduction partielle permise avec citation du document source, incluant la notice (C).

Short sections may be quoted without explicit permission, if full credit, including (C) notice, is given to the source.
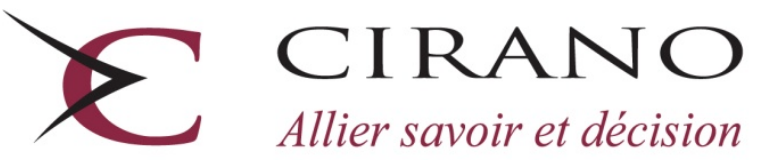

Allier savoir et décision

Centre interuniversitaire de recherche en analyse des organisations 


\section{CIRANO}

Le CIRANO est un organisme sans but lucratif constitué en vertu de la Loi des compagnies du Québec. Le financement de son infrastructure et de ses activités de recherche provient des cotisations de ses organisations-membres, d'une subvention d’infrastructure du Ministère du Développement économique et régional et de la Recherche, de même que des subventions et mandats obtenus par ses équipes de recherche.

CIRANO is a private non-profit organization incorporated under the Québec Companies Act. Its infrastructure and research activities are funded through fees paid by member organizations, an infrastructure grant from the Ministère du Développement économique et régional et de la Recherche, and grants and research mandates obtained by its research teams.

\section{Les partenaires du CIRANO}

\section{Partenaire majeur}

Ministère de l'Enseignement supérieur, de la Recherche, de la Science et de la Technologie

Partenaires corporatifs

Autorité des marchés financiers

Banque de développement du Canada

Banque du Canada

Banque Laurentienne du Canada

Banque Nationale du Canada

Banque Scotia

Bell Canada

BMO Groupe financier

Caisse de dépôt et placement du Québec

Fédération des caisses Desjardins du Québec

Financière Sun Life, Québec

Gaz Métro

Hydro-Québec

Industrie Canada

Investissements PSP

Ministère des Finances et de l'Économie

Power Corporation du Canada

Rio Tinto Alcan

State Street Global Advisors

Transat A.T.

Ville de Montréal

\section{Partenaires universitaires}

École Polytechnique de Montréal

École de technologie supérieure (ÉTS)

HEC Montréal

Institut national de la recherche scientifique (INRS)

McGill University

Université Concordia

Université de Montréal

Université de Sherbrooke

Université du Québec

Université du Québec à Montréal

Université Laval

Le CIRANO collabore avec de nombreux centres et chaires de recherche universitaires dont on peut consulter la liste sur son site web.

Les cahiers de la série scientifique (CS) visent à rendre accessibles des résultats de recherche effectuée au CIRANO afin de susciter échanges et commentaires. Ces cahiers sont écrits dans le style des publications scientifiques. Les idées et les opinions émises sont sous l'unique responsabilité des auteurs et ne représentent pas nécessairement les positions du CIRANO ou de ses partenaires.

This paper presents research carried out at CIRANO and aims at encouraging discussion and comment. The observations and viewpoints expressed are the sole responsibility of the authors. They do not necessarily represent positions of CIRANO or its partners. 


\title{
Trend-Cycle Decomposition: Implications from an Exact Structural Identification
}

\author{
Mardi Dungey ${ }^{*}$, Jan P.A.M. Jacobs ${ }^{\dagger}$, Jing Tian ${ }^{\ddagger}$, Simon van Norden ${ }^{\S}$
}

\section{Résumé / Abstract}

Une caractéristique bien connue de la décomposition Beveridge-Nelson est la corrélation négative parfaite entre les innovations aux cycles et aux tendances. Nous montrons comment cette corrélation est compatible avec des modèles structurels où les chocs aux tendances entrent par les cycles, ou les chocs aux cycles entrent par les tendances et que des restrictions d'identification sont nécessaires pour faire cette distinction structurelle. Une forme réduite sans restriction comme celle de Morley, Nelson et Zivot (2003) est compatible avec les deux options, mais ne peut pas les distinguer. Nous discutons des interprétations économiques et les implications en utilisant des données réelles du PIB américain.

A well-documented property of the Beveridge-Nelson trend-cycle decomposition is the perfect negative correlation between trend and cycle innovations. We show how this may be consistent with a structural model where trend shocks enter the cycle, or cycle shocks enter the trend and that identification restrictions are necessary to make this structural distinction. A reduced form unrestricted version such as Morley, Nelson and Zivot (2003) is compatible with either option, but cannot distinguish which is relevant. We discuss economic interpretations and implications using US real GDP data.

Keywords: trend-cycle decomposition, data revision, state-space form.

Codes JEL : C22, C53, C82

\footnotetext{
* University of Tasmania, CFAP, University of Cambridge, CAMA.

${ }^{\dagger}$ University of Groningen, University of Tasmania, CAMA and CIRANO.

${ }^{\ddagger}$ University of Tasmania.

${ }^{\S}$ Corresponding author: HEC Montréal, 3000 Chemin de la Cote Sainte Catherine, Montreal QC, H3T 2A7, 514-340-6781, simon.van-norden@hec.ca.
} 


\section{Introduction}

Decomposing macroeconomic time series into trend and cycle components has a significant history. Macroeconomics is vitally interested in distinguishing between trends and cycles in series such as GDP and employment as the profession attempts to align theory, policy and empirical estimation. Econometrics has responded with a basket of different methods including simple moving averages, fitted linear trends and sophisticated linear filters such as the Hodrick-Prescott filter and bandpass filters of Baxter and King (1999) and Christiano and Fitzgerald (2003) and the uncorrelated unobserved components (UC) models associated with Structural Time Series Analysis in Harvey (1989). ${ }^{1}$ The Beveridge-Nelson (1981; BN) decomposition which specifically accounts for the unit root properties of many macroeconomic time series has become a particularly useful tool, decomposing series into a deterministic trend, a random walk and cycle. ${ }^{2}$ Morley, Nelson and Zivot (2003; MNZ) were the first to investigate the equivalence between the UC and BN approaches.

This paper considers identification of trend cycle decompositions cast in a state-space form. We take the state-space version of the BN decomposition first provided by Morley (2002) and introduce identification insights drawn from the data revisions literature, in particular Jacobs and van Norden (2011; JvN). An important feature of this approach is that unlike the Struc-

\footnotetext{
${ }^{1}$ See Jacobs (1998), Mills (2003) and Harvey (2006) for further information.

${ }^{2}$ Although Nelson (2008) notes that it was left on the shelf for nearly a decade.
} 
2013s-23

\section{Trend-Cycle Decomposition: Implications from an Exact Structural Identification}

Mardi Dungey, Jan P.A.M. Jacobs, Jing Tian, Simon van Norden

\begin{tabular}{c}
\hline $\begin{array}{c}\text { Série Scientifique } \\
\text { Scientific Series }\end{array}$ \\
\hline
\end{tabular}

Montréal

Juillet 2013

(C) 2013 Mardi Dungey, Jan P.A.M. Jacobs, Jing Tian, Simon van Norden. Tous droits réservés. All rights reserved. Reproduction partielle permise avec citation du document source, incluant la notice (C).

Short sections may be quoted without explicit permission, if full credit, including (C) notice, is given to the source.
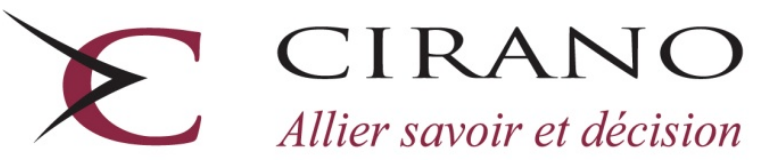

Allier savoir et décision

Centre interuniversitaire de recherche en analyse des organisations 


\section{CIRANO}

Le CIRANO est un organisme sans but lucratif constitué en vertu de la Loi des compagnies du Québec. Le financement de son infrastructure et de ses activités de recherche provient des cotisations de ses organisations-membres, d'une subvention d’infrastructure du Ministère du Développement économique et régional et de la Recherche, de même que des subventions et mandats obtenus par ses équipes de recherche.

CIRANO is a private non-profit organization incorporated under the Québec Companies Act. Its infrastructure and research activities are funded through fees paid by member organizations, an infrastructure grant from the Ministère du Développement économique et régional et de la Recherche, and grants and research mandates obtained by its research teams.

\section{Les partenaires du CIRANO}

\section{Partenaire majeur}

Ministère de l'Enseignement supérieur, de la Recherche, de la Science et de la Technologie

Partenaires corporatifs

Autorité des marchés financiers

Banque de développement du Canada

Banque du Canada

Banque Laurentienne du Canada

Banque Nationale du Canada

Banque Scotia

Bell Canada

BMO Groupe financier

Caisse de dépôt et placement du Québec

Fédération des caisses Desjardins du Québec

Financière Sun Life, Québec

Gaz Métro

Hydro-Québec

Industrie Canada

Investissements PSP

Ministère des Finances et de l'Économie

Power Corporation du Canada

Rio Tinto Alcan

State Street Global Advisors

Transat A.T.

Ville de Montréal

\section{Partenaires universitaires}

École Polytechnique de Montréal

École de technologie supérieure (ÉTS)

HEC Montréal

Institut national de la recherche scientifique (INRS)

McGill University

Université Concordia

Université de Montréal

Université de Sherbrooke

Université du Québec

Université du Québec à Montréal

Université Laval

Le CIRANO collabore avec de nombreux centres et chaires de recherche universitaires dont on peut consulter la liste sur son site web.

Les cahiers de la série scientifique (CS) visent à rendre accessibles des résultats de recherche effectuée au CIRANO afin de susciter échanges et commentaires. Ces cahiers sont écrits dans le style des publications scientifiques. Les idées et les opinions émises sont sous l'unique responsabilité des auteurs et ne représentent pas nécessairement les positions du CIRANO ou de ses partenaires.

This paper presents research carried out at CIRANO and aims at encouraging discussion and comment. The observations and viewpoints expressed are the sole responsibility of the authors. They do not necessarily represent positions of CIRANO or its partners. 


\title{
Trend-Cycle Decomposition: Implications from an Exact Structural Identification
}

\author{
Mardi Dungey ${ }^{*}$, Jan P.A.M. Jacobs ${ }^{\dagger}$, Jing Tian ${ }^{\ddagger}$, Simon van Norden ${ }^{\S}$
}

\section{Résumé / Abstract}

Une caractéristique bien connue de la décomposition Beveridge-Nelson est la corrélation négative parfaite entre les innovations aux cycles et aux tendances. Nous montrons comment cette corrélation est compatible avec des modèles structurels où les chocs aux tendances entrent par les cycles, ou les chocs aux cycles entrent par les tendances et que des restrictions d'identification sont nécessaires pour faire cette distinction structurelle. Une forme réduite sans restriction comme celle de Morley, Nelson et Zivot (2003) est compatible avec les deux options, mais ne peut pas les distinguer. Nous discutons des interprétations économiques et les implications en utilisant des données réelles du PIB américain.

A well-documented property of the Beveridge-Nelson trend-cycle decomposition is the perfect negative correlation between trend and cycle innovations. We show how this may be consistent with a structural model where trend shocks enter the cycle, or cycle shocks enter the trend and that identification restrictions are necessary to make this structural distinction. A reduced form unrestricted version such as Morley, Nelson and Zivot (2003) is compatible with either option, but cannot distinguish which is relevant. We discuss economic interpretations and implications using US real GDP data.

Keywords: trend-cycle decomposition, data revision, state-space form.

Codes JEL : C22, C53, C82

\footnotetext{
* University of Tasmania, CFAP, University of Cambridge, CAMA.

${ }^{\dagger}$ University of Groningen, University of Tasmania, CAMA and CIRANO.

${ }^{\ddagger}$ University of Tasmania.

${ }^{\S}$ Corresponding author: HEC Montréal, 3000 Chemin de la Cote Sainte Catherine, Montreal QC, H3T 2A7, 514-340-6781, simon.van-norden@hec.ca.
} 
tural Time Series approach, where shocks to trends and cycles are typically assumed to be uncorrelated, shocks are negatively correlated. Several recent papers argue that output data are better fit by models with negatively correlated shocks, including; MNZ, Oh, Zivot and Creal (2008), Sinclair (2009), Morley (2011), and Jun et al. (2011), while Nelson (2008) also finds that models with negatively correlated shocks do as well or better at forecasting cyclic movements than models with uncorrelated shocks. ${ }^{3}$ Non-zero correlations between shocks in state-space models result in unequal weights on future and past values in the Kalman smoother (see Harvey and Koopman, 2000). Proietti (2006) notes that negative correlations lead to higher weights on future observations in the Kalman smoother, resulting in relatively large revisions to filtered estimates.

In spite of the above evidence favouring negatively correlated shocks to trend and cycle, the economic interpretation of this correlation is the subject of considerable debate. The dominant view is that trend innovations lead to a requirement for cycles to 'catch up', so that the deviation of the cycle from the shifted long run path diminishes over time, resulting in a negative correlation. However, cycle shocks do not cause an analogous move in trend. This view (long associated with Charles Nelson) implies that potential output is more volatile than observed output. This is consistent with the predominance of real shocks which directly affect potential output but not actual output.

In contrast, cycle shocks may be considered to influence the trend. In this

\footnotetext{
${ }^{3}$ Perron and Wada (2009) take a different view, and emphasize the role of breaks.
} 
case the literature interprets the results as supporting the effect of nominal shocks in determining long term economic outcomes, and a stronger role for macroeconomic policy, particularly that monetary policy decisions or government expenditure or income changes may influence the equilibrium outcome path for an economy. The specification of whether trend shocks influence cycle, or cycle shocks influence trend is non-trivial, and has important implications for both policy and economic forecasting, see Nelson (2008), Morley (2011) and Evans and Reichlin (1994).

We show the difficulties in obtaining a structural form identification for the interactions between shocks to trend and shocks to cycle in the general state-space form of the BN decomposition as provided in MNZ, also noted by Proietti (2006) and Weber (2011), and how these may be resolved with assumptions adopted from JvN. By way of illustration we apply these to US GDP and show that the data supports the interpretation of cycle shocks influencing trend rather than the alternative that trend shocks influence cycle. This conclusion contributes to the ongoing debate about whether real shocks drive the economy, and nominal shocks are only temporary or the alternative that nominal (cycle) shocks may indeed influence long term economic outcomes.

The remainder of this paper is structured as follows. First, in Section 2 we introduce the modeling framework to illustrate different assumptions that may be used in trend-cycle decompositions and consider different interpretations associated with these assumptions. Section 3 provides the empirical 
application to US real GDP data and discusses the evidence for whether cycle shocks enter trend or trend shocks enter cycle. Section 4 concludes.

\section{A simple model for decompositions with multiple interpretations}

Consider the decomposition

$$
y_{t}=\widetilde{y}_{t}+e_{t},
$$

where $y_{t}$ is observable, $\widetilde{y}_{t}$ is a latent variable, and $e_{t} \equiv y_{t}-\widetilde{y}_{t}$. We will assume that $\widetilde{y}_{t}$ is a random walk — which is equivalent to $\Delta \widetilde{y}_{t}$ being i.i.d.- - but we will make no identifying assumptions about $e_{t}$ for the moment. Although macroeconomists can easily think of $\tilde{y}_{t}$ as trend and $e_{t}$ as cycle, this decomposition is also entirely compatible with the JvN approach of $\tilde{y}_{t}$ as the "truth" and $e_{t}$ as measurement errors as will be shown below.

We can write one such very simple model in state-space form as

$$
\begin{aligned}
\text { Measurement Equation } y_{t} & =\left[\begin{array}{ll}
1 & 1
\end{array}\right] \cdot\left[\begin{array}{l}
\widetilde{y}_{t} \\
e_{t}
\end{array}\right] \\
\text { Transition Equation } & {\left[\begin{array}{l}
\widetilde{y}_{t} \\
e_{t}
\end{array}\right]=\left[\begin{array}{ll}
1 & 0 \\
0 & 0
\end{array}\right] \cdot\left[\begin{array}{l}
\widetilde{y}_{t-1} \\
e_{t-1}
\end{array}\right]+\left[\begin{array}{cc}
\sigma_{\eta} & 0 \\
0 & \sigma_{\nu}
\end{array}\right] \cdot\left[\begin{array}{l}
\eta_{t} \\
\nu_{t}
\end{array}\right], }
\end{aligned}
$$


where $\left[\begin{array}{ll}\eta_{t} & \nu_{t}\end{array}\right]^{\prime} \sim$ i.i.d. $N\left(\mathbf{0}, \boldsymbol{I}_{2}\right)$. Note that since $y_{t}$ is just $\widetilde{y}_{t}$ plus i.i.d. noise, $\operatorname{var}\left(\Delta y_{t}\right)>\operatorname{var}\left(\Delta \tilde{y}_{t}\right), \forall \sigma_{\nu}>0$.

The model implies $y_{t} \sim \operatorname{IMA}(1,1)$, which might not be realistic. In particular, if $y_{t}$ is thought to contain cycles we can nest this possibility by allowing $e_{t}$ to follow an $\mathrm{AR}(2)$ process, as in MNZ. Now the measurement equation becomes

$$
y_{t}=\left[\begin{array}{lll}
1 & 1 & 0
\end{array}\right] \cdot\left[\begin{array}{c}
\widetilde{y}_{t} \\
e_{t} \\
e_{t-1}
\end{array}\right]
$$

with transition equation

$$
\left[\begin{array}{c}
\widetilde{y}_{t} \\
e_{t} \\
e_{t-1}
\end{array}\right]=\left[\begin{array}{ccc}
1 & 0 & 0 \\
0 & \phi_{1} & \phi_{2} \\
0 & 1 & 0
\end{array}\right] \cdot\left[\begin{array}{l}
\widetilde{y}_{t-1} \\
e_{t-1} \\
e_{t-2}
\end{array}\right]+\left[\begin{array}{cc}
\sigma_{\eta} & 0 \\
0 & \sigma_{\nu} \\
0 & 0
\end{array}\right] \cdot\left[\begin{array}{c}
\eta_{t} \\
\nu_{t}
\end{array}\right]
$$

In the cycle decomposition literature the final term in Equation (4) is usually expressed as

$$
\left[\begin{array}{c}
\tilde{\eta}_{t} \\
\tilde{\nu}_{t} \\
0
\end{array}\right]=\left[\begin{array}{cc}
\sigma_{\eta} & 0 \\
0 & \sigma_{\nu} \\
0 & 0
\end{array}\right] \cdot\left[\begin{array}{c}
\eta_{t} \\
\nu_{t}
\end{array}\right]
$$

where $\tilde{\eta}_{t}$ is the 'trend' shock and $\tilde{\nu}_{t}$ is the 'cycle' shock.

While this is consistent with the prototypical unobserved components model of the business cycle with orthogonal shocks, i.e. the seminal model 
of Watson (1986), orthogonality is not essential. We could instead assume that the shocks are perfectly correlated, which results in the Single Source of Error (SSE) decomposition of Anderson, Low and Snyder (2006), with transition equation

$$
\left[\begin{array}{c}
\widetilde{y}_{t} \\
e_{t} \\
e_{t-1}
\end{array}\right]=\left[\begin{array}{ccc}
1 & 0 & 0 \\
0 & \phi_{1} & \phi_{2} \\
0 & 1 & 0
\end{array}\right] \cdot\left[\begin{array}{c}
\widetilde{y}_{t-1} \\
e_{t-1} \\
e_{t-2}
\end{array}\right]+\left[\begin{array}{c}
\sigma_{\eta} \\
\sigma_{\nu} \\
0
\end{array}\right] \cdot\left[\eta_{t}\right]
$$

Alternatively, we can encompass Equations (4) and (5) in the form

$$
\left[\begin{array}{c}
\widetilde{y}_{t} \\
e_{t} \\
e_{t-1}
\end{array}\right]=\left[\begin{array}{ccc}
1 & 0 & 0 \\
0 & \phi_{1} & \phi_{2} \\
0 & 1 & 0
\end{array}\right] \cdot\left[\begin{array}{c}
\widetilde{y}_{t-1} \\
e_{t-1} \\
e_{t-2}
\end{array}\right]+\left[\begin{array}{cc}
\sigma_{\eta} & r_{12} \\
r_{21} & \sigma_{\nu} \\
0 & 0
\end{array}\right] \cdot\left[\begin{array}{c}
\eta_{t} \\
\nu_{t}
\end{array}\right]
$$

where $r_{12}$ and $r_{21}$ are non-zero.

The critical component of estimating such models in state-space format is the variance-covariance matrix of the shocks, denoted $\boldsymbol{Q}$. In our most general case, given in Equation (6), the relevant form is given as:

$\mathrm{E}\left(\left[\begin{array}{cc}\sigma_{\eta} & r_{12} \\ r_{21} & \sigma_{\nu} \\ 0 & 0\end{array}\right]\left[\begin{array}{l}\eta_{t} \\ \nu_{t}\end{array}\right]\left[\begin{array}{c}\eta_{t} \\ \nu_{t}\end{array}\right]^{\prime}\left[\begin{array}{cc}\sigma_{\eta} & r_{12} \\ r_{21} & \sigma_{\nu} \\ 0 & 0\end{array}\right]^{\prime}\right)=\left[\begin{array}{ccc}\sigma_{\eta}^{2}+r_{12}^{2} & \sigma_{\eta} r_{21}+\sigma_{\nu} r_{12} & 0 \\ \sigma_{\eta} r_{21}+\sigma_{\nu} r_{12} & \sigma_{\nu}^{2}+r_{21}^{2} & 0 \\ 0 & 0 & 0\end{array}\right]$,

that is $\mathrm{E}\left(\boldsymbol{R} \varepsilon \varepsilon^{\prime} \boldsymbol{R}^{\prime}\right)=\boldsymbol{Q}$. 
Estimation of (6) allows us to exactly identify the three elements in $\boldsymbol{Q}$. However, the four elements in $\boldsymbol{R}$ are not identified. We may instead entertain a number of restrictions on $\boldsymbol{R}$ consistent with economic argument. For example, if only real (that is trend) economic shocks have long term effects, then cycle (or nominal) shocks will not have a sustained influence. This implies $r_{12}=0$ and $\boldsymbol{Q}$ simplifies to:

$$
\mathrm{E}\left(\left[\begin{array}{cc}
\sigma_{\eta} & 0 \\
r_{21} & \sigma_{\nu} \\
0 & 0
\end{array}\right]\left[\begin{array}{l}
\eta_{t} \\
\nu_{t}
\end{array}\right]\left[\begin{array}{l}
\eta_{t} \\
\nu_{t}
\end{array}\right]^{\prime}\left[\begin{array}{cc}
\sigma_{\eta} & 0 \\
r_{21} & \sigma_{\nu} \\
0 & 0
\end{array}\right]^{\prime}\right)=\left[\begin{array}{ccc}
\sigma_{\eta}^{2} & \sigma_{\eta} r_{21} & 0 \\
\sigma_{\eta} r_{21} & r_{21}^{2}+\sigma_{\nu}^{2} & 0 \\
0 & 0 & 0
\end{array}\right] .
$$

We also entertain the opposite case, where trend shocks do not influence the cycle but cycle shocks affect trend, which implies $r_{21}=0$ and $\boldsymbol{Q}$ simplifies to:

$$
\mathrm{E}\left(\left[\begin{array}{cc}
\sigma_{\eta} & r_{12} \\
0 & \sigma_{\nu} \\
0 & 0
\end{array}\right]\left[\begin{array}{l}
\eta_{t} \\
\nu_{t}
\end{array}\right]\left[\begin{array}{c}
\eta_{t} \\
\nu_{t}
\end{array}\right]^{\prime}\left[\begin{array}{cc}
\sigma_{\eta} & r_{12} \\
0 & \sigma_{\nu} \\
0 & 0
\end{array}\right]^{\prime}\right)=\left[\begin{array}{ccc}
\sigma_{\eta}^{2}+r_{12}^{2} & \sigma_{\nu} r_{12} & 0 \\
\sigma_{\nu} r_{12} & \sigma_{\nu}^{2} & 0 \\
0 & 0 & 0
\end{array}\right] .
$$

These two models are observationally equivalent to the unrestricted UC model of MNZ, and are hence labelled Unrestricted-Trend-Shocks-in-Cycle (UT2C) and Unrestricted-Cycle Shocks-in-Trend-in-Cycle (UT2C) models, respectively. This is consistent with the fact that while MNZ (p.241) write "If we accept the implication that innovations to trend are strongly negatively 
correlated with innovations to the cycle, then the case for the importance of real shocks in the macro economy is strengthened", Proietti (2006) shows that this need not always be the case.

An alternative interpretation of our original model is as a measurement error model where $e_{t}$ is the measurement error in observing our object of interest $\widetilde{y}_{t}$. Typical measurement error models assume that $E\left(\widetilde{y}_{t} \cdot e_{t}\right)=0$; so that what we observe is the 'truth' plus a random 'noise' term $e_{t}$. However, we might prefer to think of measurement error as 'news' rather than 'noise', so that $E\left(y_{t} \cdot e_{t}\right)=0$. This would be more consistent with the idea of an "efficient" statistical agency as suggested by Sargent (1989), for example. In that case, the transition equations become

$$
\left[\begin{array}{c}
\widetilde{y}_{t} \\
e_{t} \\
e_{t-1}
\end{array}\right]=\left[\begin{array}{ccc}
1 & 0 & 0 \\
0 & \phi_{1} & \phi_{2} \\
0 & 1 & 0
\end{array}\right] \cdot\left[\begin{array}{c}
\widetilde{y}_{t-1} \\
e_{t-1} \\
e_{t-2}
\end{array}\right]+\left[\begin{array}{cc}
\sigma_{\eta} & -\sigma_{\nu} \\
0 & \sigma_{\nu} \\
0 & 0
\end{array}\right] \cdot\left[\begin{array}{c}
\eta_{t} \\
\nu_{t}
\end{array}\right],
$$

where now $\eta_{t}$ is the 'truth' shock and $\nu_{t}$ is the 'news' shock, and we have allowed the measurement errors to be correlated over time. Note that for any observation $y_{t}$, the news shock in the 'truth' $\tilde{y}_{t}$ is exactly offset by the shock in the measurement error $e_{t}$, so that only the portion of the shock due to $\eta_{t}$ is initially observable. This model is a special case of the UC2T model 
introduced above, with the additional restriction $r_{12}=-\sigma_{\nu}$ so that

$$
\boldsymbol{Q}=\left[\begin{array}{ccc}
\sigma_{\eta}^{2}+\sigma_{\nu}^{2} & -\sigma_{\nu}^{2} & 0 \\
-\sigma_{\nu}^{2} & \sigma_{\nu}^{2} & 0 \\
0 & 0 & 0
\end{array}\right]
$$

We refer to this as the Restricted-Cycle-in-Trend (RC2T) model. Alternatively, we could impose the restriction $r_{21}=-\sigma_{\eta}$ on the UT2C model, to obtain the Restricted-Trend-in-Cycle (RT2C) model, with

$$
\boldsymbol{Q}=\left[\begin{array}{ccc}
\sigma_{\eta}^{2} & -\sigma_{\eta}^{2} & 0 \\
-\sigma_{\eta}^{2} & \sigma_{\eta}^{2}+\sigma_{\nu}^{2} & 0 \\
0 & 0 & 0
\end{array}\right]
$$

In this case, in any observation $y_{t}$, the trend shock to the 'truth' $\tilde{y}_{t}$ is exactly offset by the shock in the measurement error $e_{t}$, so that only the portion of the shock due to the cyclical shock $\nu_{t}$ is initially observable. Both the RC2T and RT2C model imply that $\operatorname{var}\left(\Delta y_{t}\right)<\operatorname{var}\left(\Delta \tilde{y}_{t}\right)$ for all $\sigma_{\nu}>0$.

The different assumptions and interpretations just described capture the essential differences between a number of important and much more general state-space models. The difference between $E\left(\widetilde{y}_{t} \cdot e_{t}\right)=0$ and $E\left(y_{t} \cdot e_{t}\right)=$ 0 captures the essential difference between Structural Time Series Models (which use the former assumption) and the BN decomposition (which uses the latter). The BN trend-cycle decomposition interprets the results as a 
stochastic trend and a cycle, while the JvN approach interprets them as a "true value" contaminated by measurement error. All of these models also have multivariate extensions that may play important roles in the identification of the model; for example, see Morley (2011).

\section{Estimations}

To examine these findings we estimate various specifications of the unobserved component models that have been discussed in the previous section using U.S. real GDP data from 1947Q1 to 2012Q3. ${ }^{4}$ Table 1 compares the implied estimates of the $\boldsymbol{R}$ matrix across the three observationallyequivalent models discussed above (MNZ) and the unrestricted trend-shocksinto-cycle model (UT2C) associated with the Q matrix in Equation (8) and the unrestricted cycles-shocks-into-trend model (UC2T) with the Q matrix in Equation(9). Estimates for the drift term in the trend process and the autoregressive parameters for the cycle process and the log likelihood value are the same for all three models. The estimates for the elements of $R$ show that the MNZ specification is compatible with very different structural models of cycle and trends. On the one hand, the UT2C model has a relatively

\footnotetext{
${ }^{4} \mathrm{MNZ}$ used the same data series ending in 1998Q2. We follow them in fitting the model to 100 times the natural logarithm of the series. We also re-estimated all our models on the 1947-98 sample used by MNZ and obtained results very similar to those reported below. All estimates were produced using the CMLmt package in GAUSS to maximize the likelihood function. Two constraints were imposed in estimation: the $\operatorname{AR}(2)$ coefficients were constrained to ensure a stationary cycle and models with multiple sources of shocks were constrained to have a positive definite shock covariance matrix. These constraints were never binding at the maximum likelihood estimates.
} 
small coefficient $(0.32)$ on the cyclical shock $\nu$ while the impact of the trend shock $\eta$ is more than twice as large $(-0.76)$. This is consistent with the view that business cycles are dominated by the impact of permanent, real shocks. On the other hand, the UC2T model has the opposite result, with innovations to the trend dominated by cyclical, nominal shocks $(-1.14)$ rather than permanent real shocks $(0.48) .5$

Table 2 compares the estimated parameters of the MNZ model with five nested models, each of which imposes a different restriction. In addition to the RT2C and RC2T models, the table shows the original Beveridge-Nelson (BN) model, the Single-Source of Error (SSE) model, and the Watson (1986) model. Robust t-ratios are reported in brackets next to each parameter estimate, and parameters significantly different from zero based on a twosided standard normal distribution are indicated in boldface. Likelihoodratio (LR) statistics test the restrictions imposed by each model on the MNZ model. Figures in the Appendix show filtered and smoothed estimates of the cycle, together with 95 per cent confidence intervals, for all six models in Table 2 .

The parameter estimates for the MNZ model are similar to those reported by MNZ (2003). In addition to the familiar 'hump-shaped' AR(2) coefficients, we find the variance of shocks to the trend to be just over double the variance of shocks to the cycle, and the covariance of the shocks is strongly negative.

\footnotetext{
${ }^{5}$ The UC2T model estimates imply that positive cyclical shocks permanently 'lower' trend output.
} 


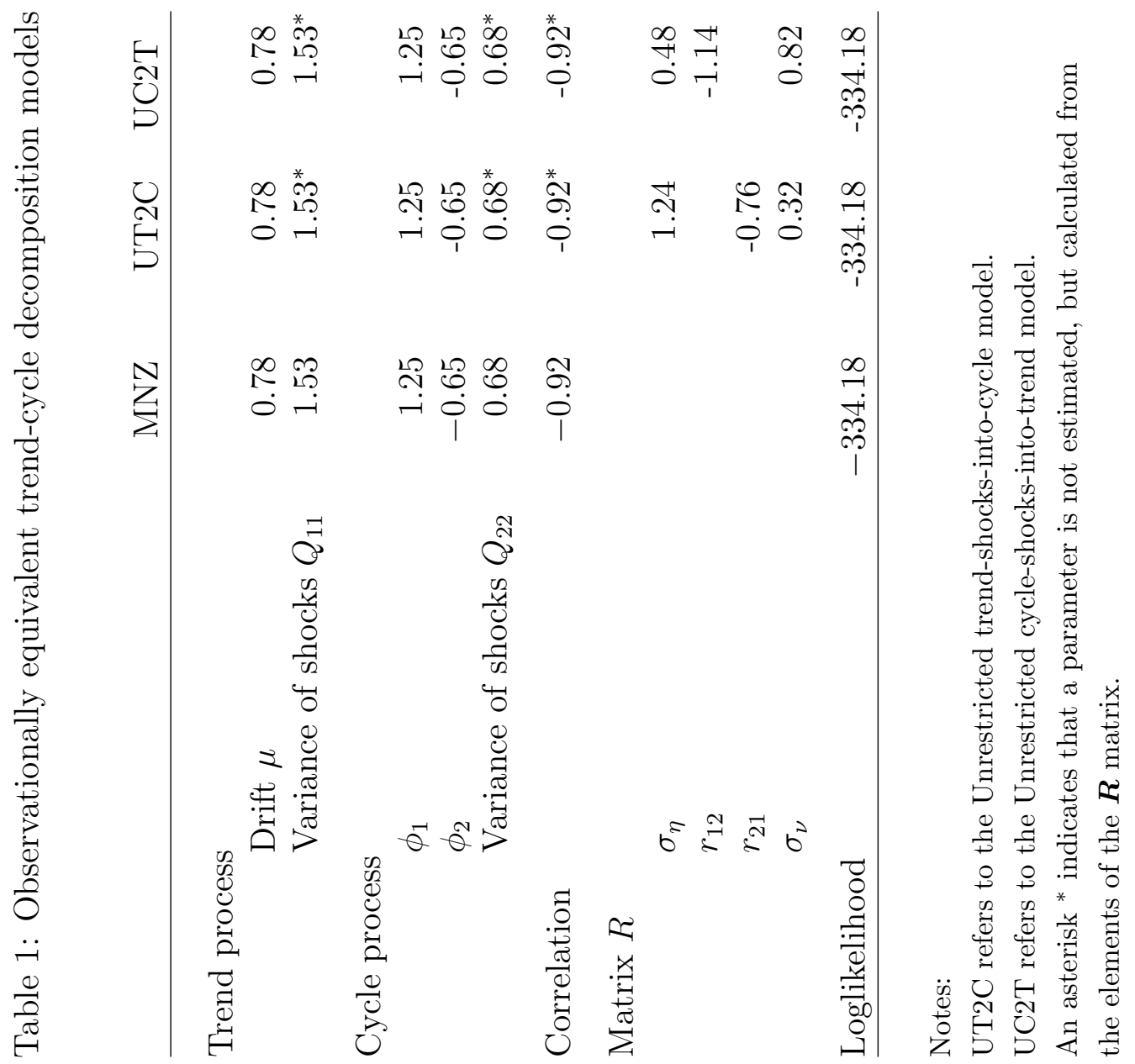




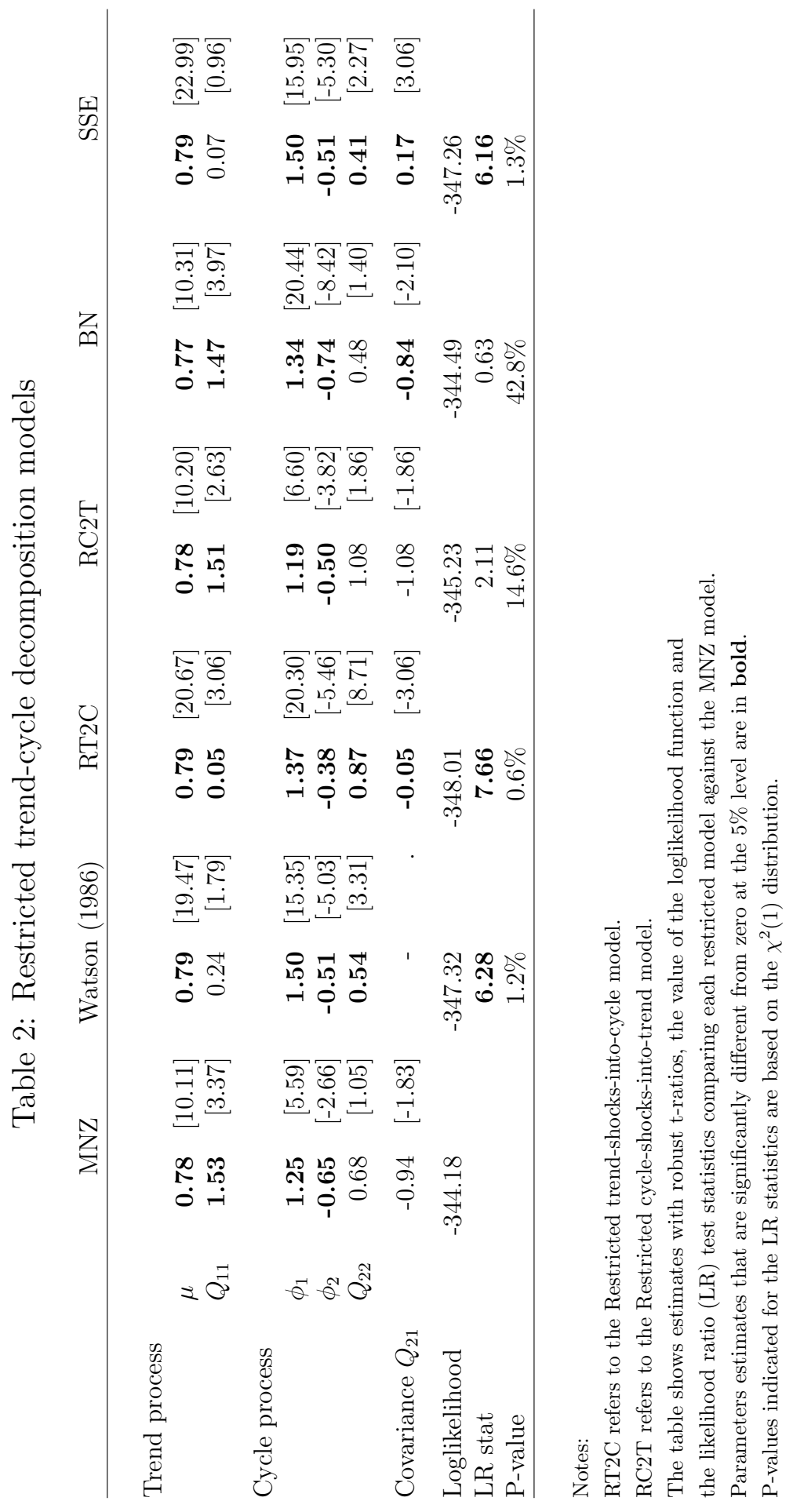


While the covariance of -0.94 is not (quite) significantly different from zero at the 5 per cent level based on its robust t-ratio, the LR test comparing the Watson and MNZ models allows a rejection of the same hypothesis at almost the 1 per cent level and is typically considered to be more reliable in finite samples. Note also that the variance of shocks to the cycle is very imprecisely estimated; this reflects in part a high correlation between the estimated variance and the estimated covariance of the shocks.

Two models fit the data almost as well as the MNZ model; the original Beveridge-Nelson model and the RC2T model. ${ }^{6}$ LR statistics are unable to reject either model at even the 10 per cent significance level. In addition to having estimated cyclic dynamics similar to that of the MNZ model, both also estimate trend shocks to be much more variable than cyclic shocks. Although the variance of the cyclic shocks remained imprecise, higher estimated variances were associated with more negative covariances. ${ }^{7}$

Figure 1 compares the smoothed and filtered estimates of the cycle for the MNZ, BN and RC2T models and shows that they are extremely similar. All three models produce smoothed estimates of the cycle that are much more variable than filtered estimates, implying that while cycles are initially estimated to be quite small, these estimates subsequently undergo substantial revision. As the figure shows, while filtered estimates of the cycle only rarely

\footnotetext{
${ }^{6}$ Weber (2011) also supports a cycle into trend specification for the majority of the sample used here

${ }^{7}$ The covariance for the RC2T model implies a correlation between the two shocks of -0.85 .
} 
exceed 1 per cent of GDP, smoothed estimates are occasionally four times as large. For example, during the most recent recession, filtered estimates from all three models initially indicated an important recession with output roughly 1 per cent below trend in early 2009. Recent smoothed estimates, however, revise that figure to near-zero and instead put 2008 output at 4 per cent above trend (the highest cyclic peak in the post-1947 period). The extensive revision of filtered estimates is reflected in their estimated standard errors; filtered estimates of the cycle for these three models are never remotely close to being statistically different from zero at conventional levels of significance. (See Appendix Figures 3 to 8.)

In contrast to these three similar models, the other three models (Watson, RT2C and SSE) do not fit the data as well and produce distinctly different results. All three produce cycles with very highly persistent $\mathrm{AR}(2)$ dynamics. (The sum of the AR coefficients is 0.99 for all three models.) Each estimates the variance of shocks to the cycle to be at least twice that of the shocks to the trend; in the case of the RT2C model, they are more than ten times larger. However, when compared to the MNZ model, each of these models is strongly rejected by the data. ${ }^{8}$

\footnotetext{
${ }^{8}$ This may reflect the weakness of these models in explaining the time-varying trend growth rate of output over the past sixty years. Faced with faster growth in the earlier part of the sample, they use a nearly non-stationary cycle to capture an upwards trend that plateaus in the early 1970s, coincident with the growth slowdown.
} 


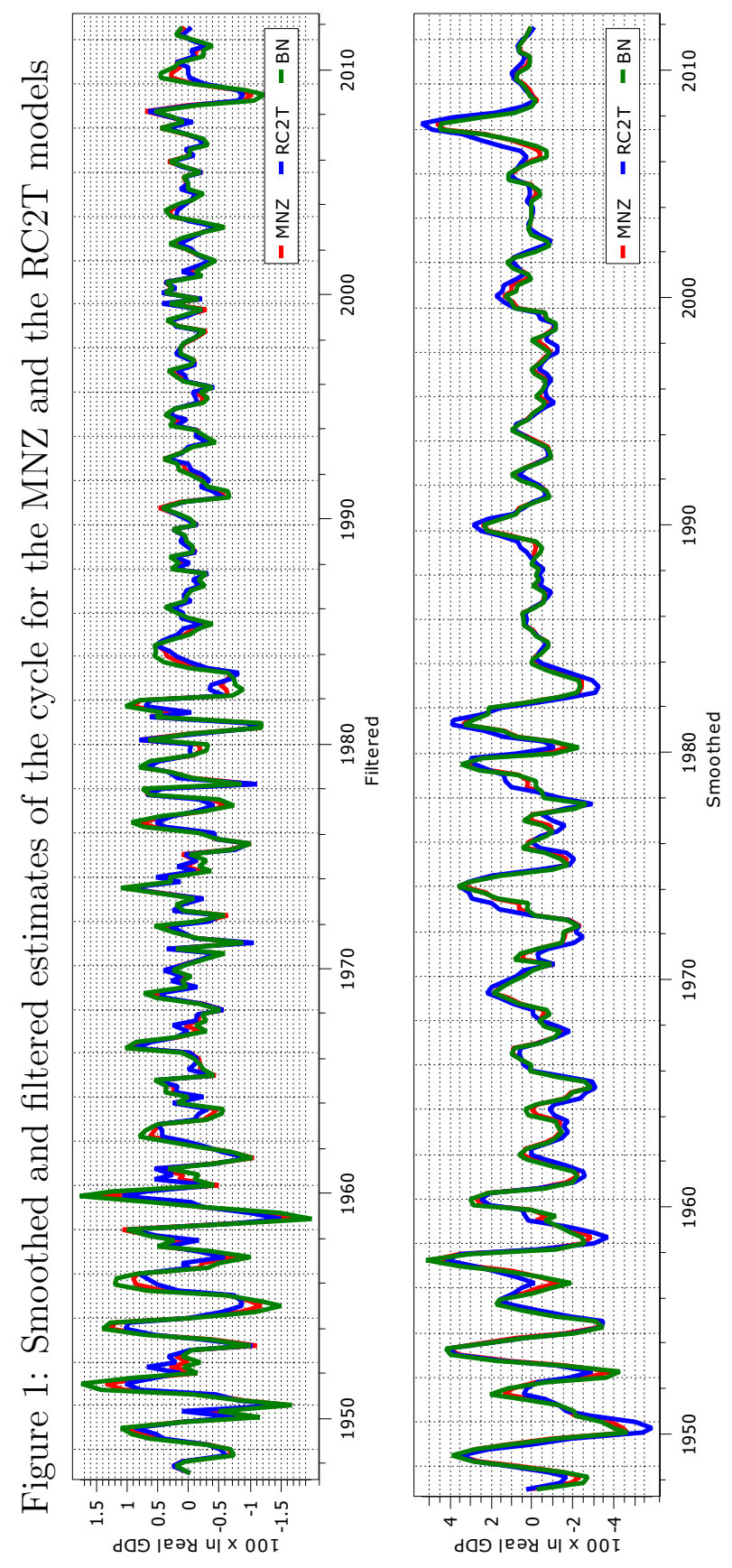


Figure 2 compares the smoothed and filtered estimates of the cycle for the Watson and the RT2C models. (Estimates for the SSE model, shown in the Appendix, are similar.) Estimated cycles are large and highly persistent; filtered estimates were consistently positive for twenty years starting in the early 1960s. Filtered estimates of the most recent recession are without precedent, implying non-stop decline relative to trend since 2006, culminating in a cycle eight per cent below trend by 2012Q3. ${ }^{9}$ The largest revisions of the filtered estimates occur at the start of the sample, with estimates for the 1940s and early 1950s revised downwards by five per cent of GDP or more. While the estimated standard errors for both the smoothed and filtered estimates from these models are large, smoothed estimates are occasionally significantly different from zero at the five per cent level, as are filtered estimates from the SSE model. Neither the Watson nor the RT2C model finds that current estimates of the cycle are significantly different from zero, which is perhaps surprising given their size.

\footnotetext{
${ }^{9}$ Smoothed estimates imply a deeper recession in 1950 . However, caution should be exercised in making this comparison as recent estimates of the cycle may yet undergo substantial revision.
} 


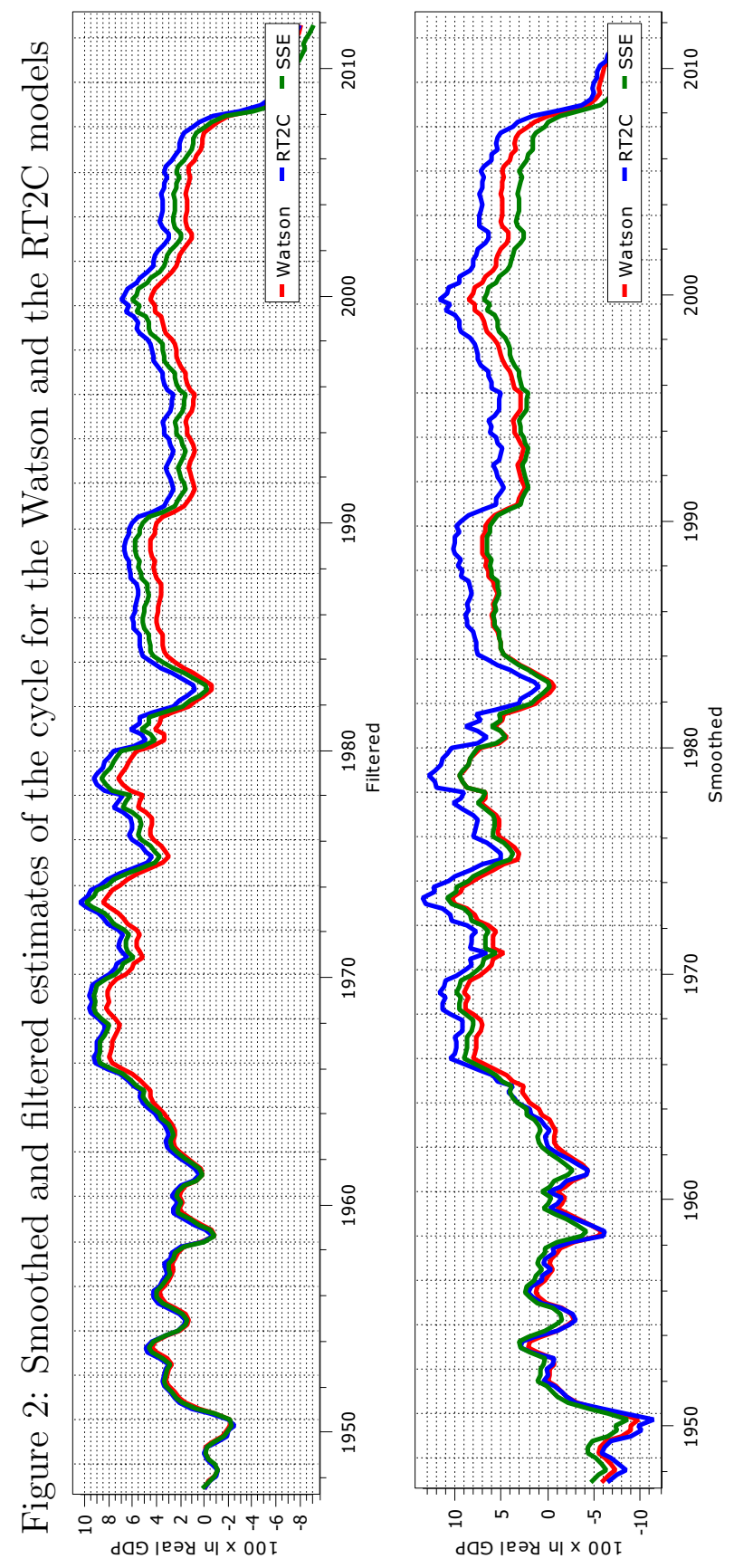




\section{Conclusion}

Trend-cycle decompositions are deeply important to macroeconomics and econometrics, and the implementation and identification assumptions used in cycle extraction influence the estimated outcomes. This paper draws insights from the identification conditions used in state-space formulation of the structure of data revisions in JvN to motivate an identification scheme in the BN equivalent state-space formulation of business cycle trend-cycle decomposition ensuring negative correlation between trend and cycle shocks. Most authors are agreed that shocks to GDP are predominantly permanent and negatively correlated. Indeed, recently Sinclair (2009) has found the same for unemployment, and noted the importance of this commonality between GDP and unemployment for Okun's law.

We show that using a state-space formulation for trend-cycle time series, such as GDP, will not ensure a structural interpretation of whether cycle shocks enter trend or trend shocks enter cycle. Instead, we implement restricted models which do admit such an interpretation. When applied to US GDP data we find that the results for 1947Q1 to 2012Q3 are more consistent with a model where cycle shocks enter trend, rather than when trend shocks enter cycle. There is some support for this result in the existing literature in the two-regime model for industrial production of Weber (2011). Furthermore, all of the models consistent with the data (BN, MNZ and RC2T) imply that smoothed cyclical fluctuations are many times larger than filtered 
cycles, reflecting that filtered estimates are not reliable indicators of business cycles.

The paper shows how the parallels between the trend-cycle decompositions literature and the data revisions literature may be used to aid in identification when there is assumed to be negative correlation between the two types of shocks - the common presumption in both literatures. Using these parallels we explore the relationships between trend and cycle shocks and which may provide the driving influence in an economy. In this way the paper seeks to align economic theory and econometric technique in the spirit of, for example, Lee and Nelson (2007) and Murray and Nelson (2004). 


\section{Appendix}

Figure 3: Smoothed and filtered estimates of the cycle for the MNZ model
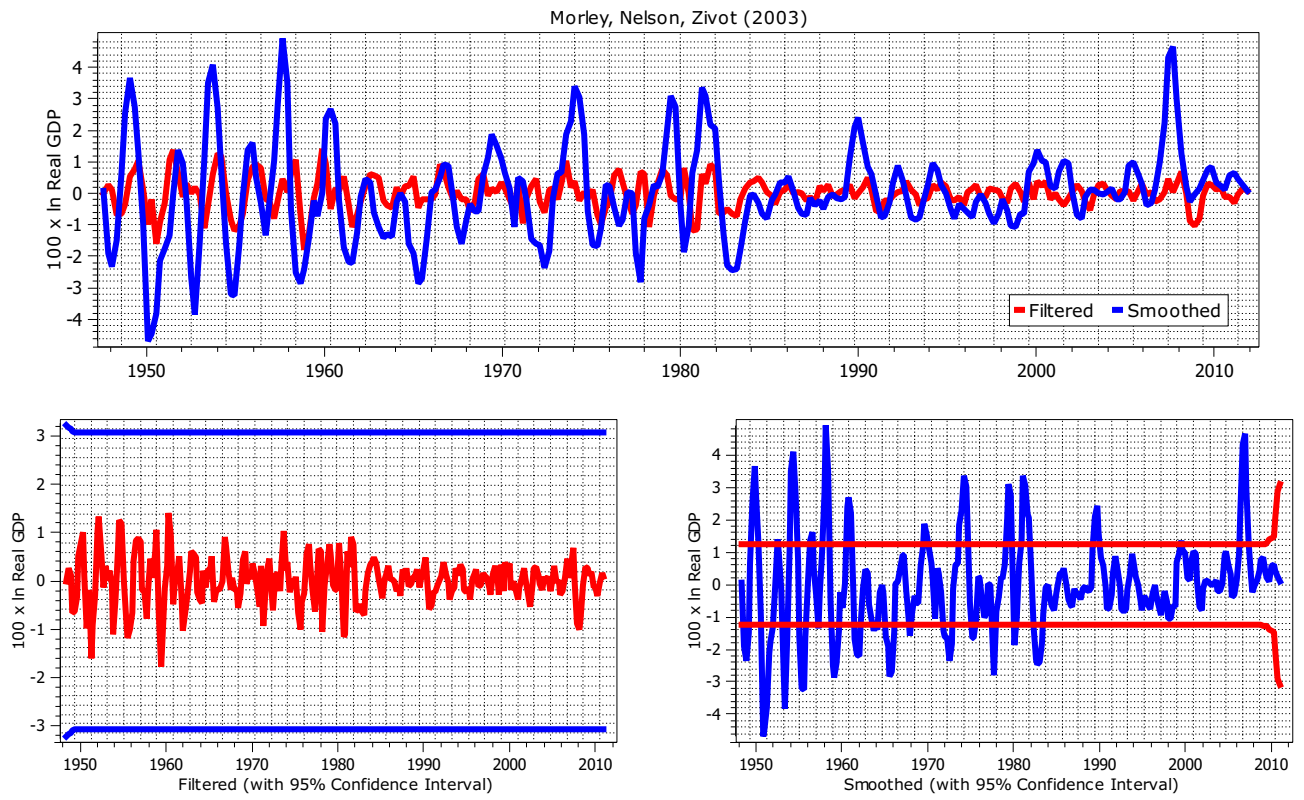
Figure 4: Smoothed and filtered estimates of the cycle for the Watson model
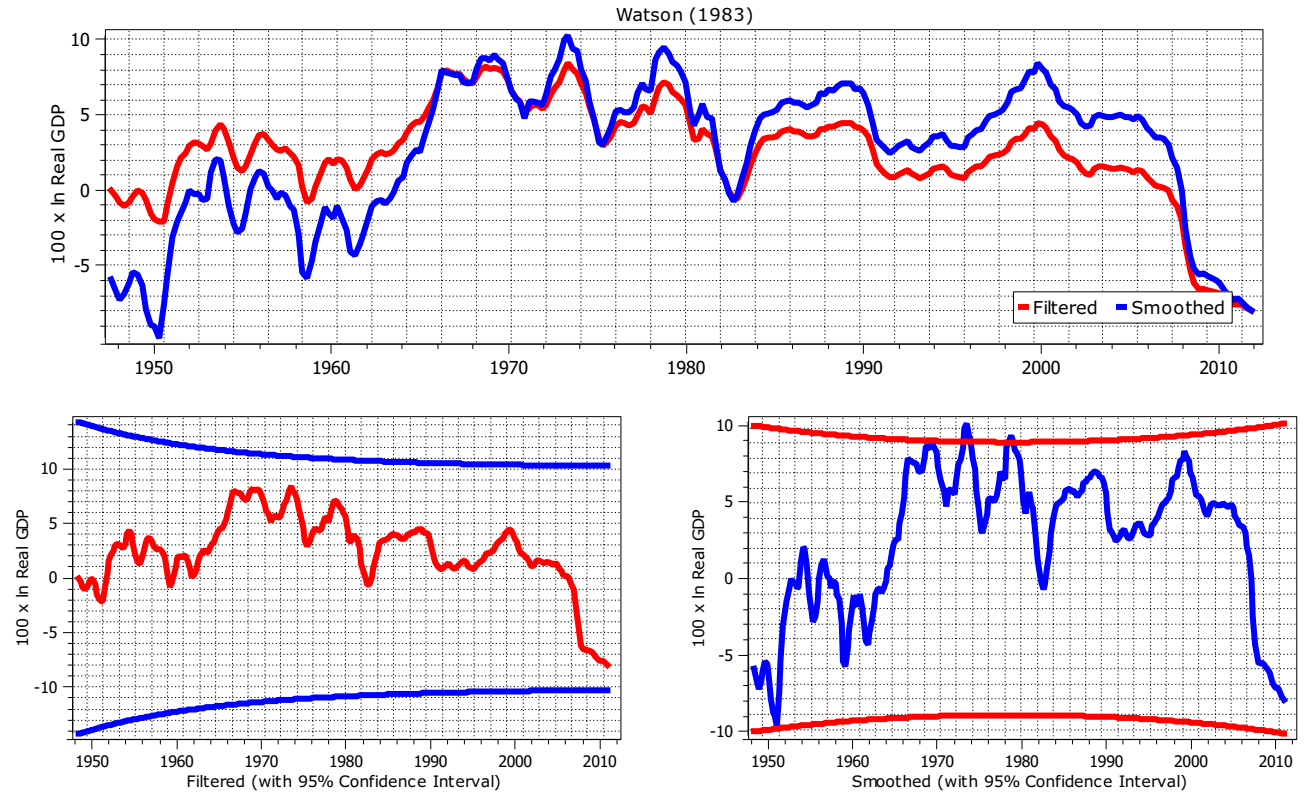
Figure 5: Smoothed and filtered estimates of the cycle for the RT2C model
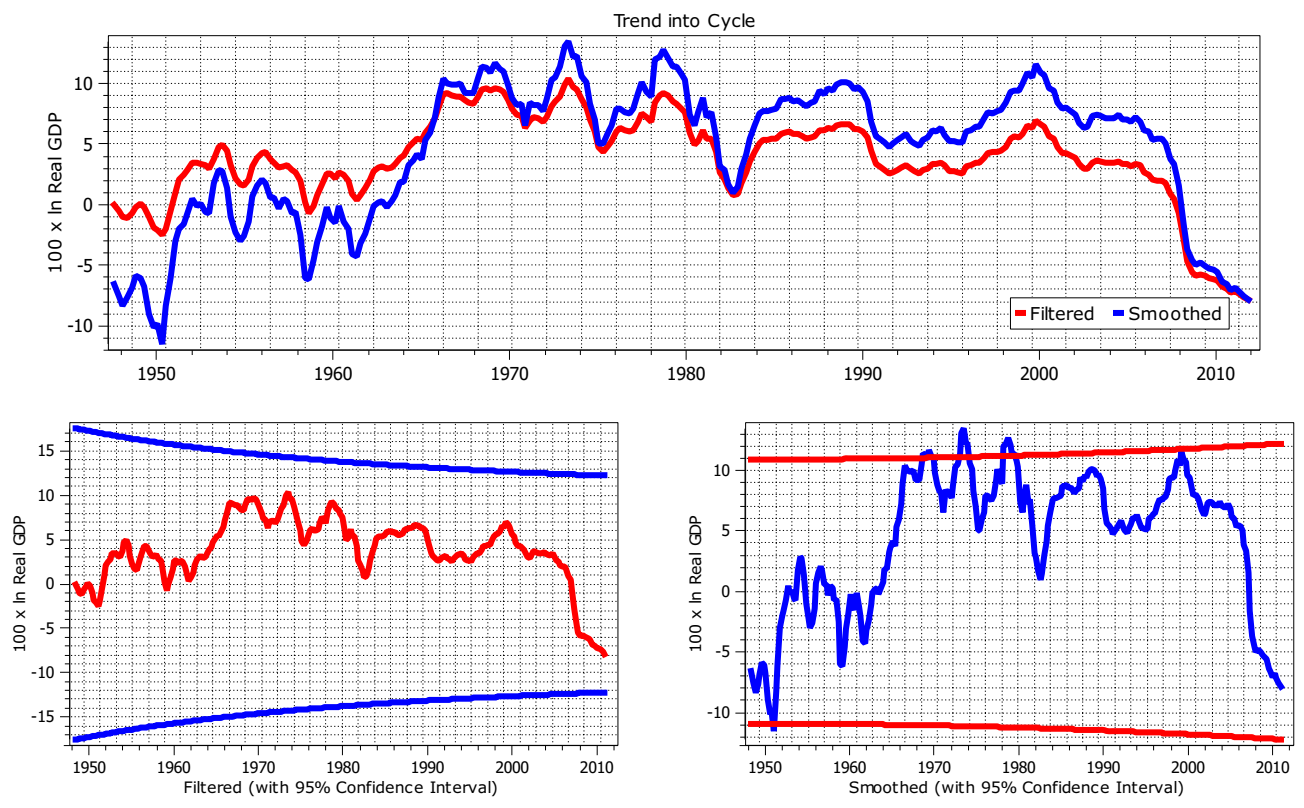
Figure 6: Smoothed and filtered estimates of the cycle for the $\mathrm{RC} 2 \mathrm{~T}$ model
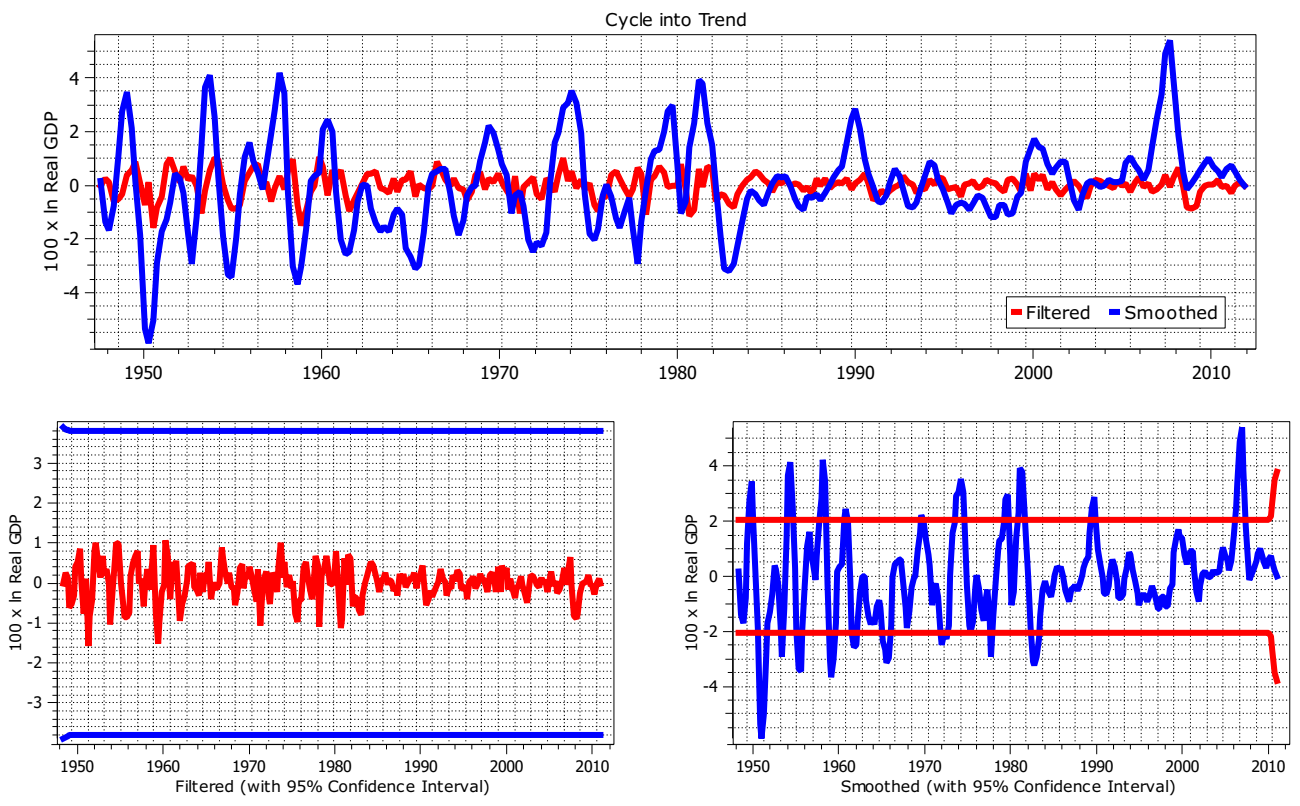
Figure 7: Smoothed and filtered estimates of the cycle for the BN model
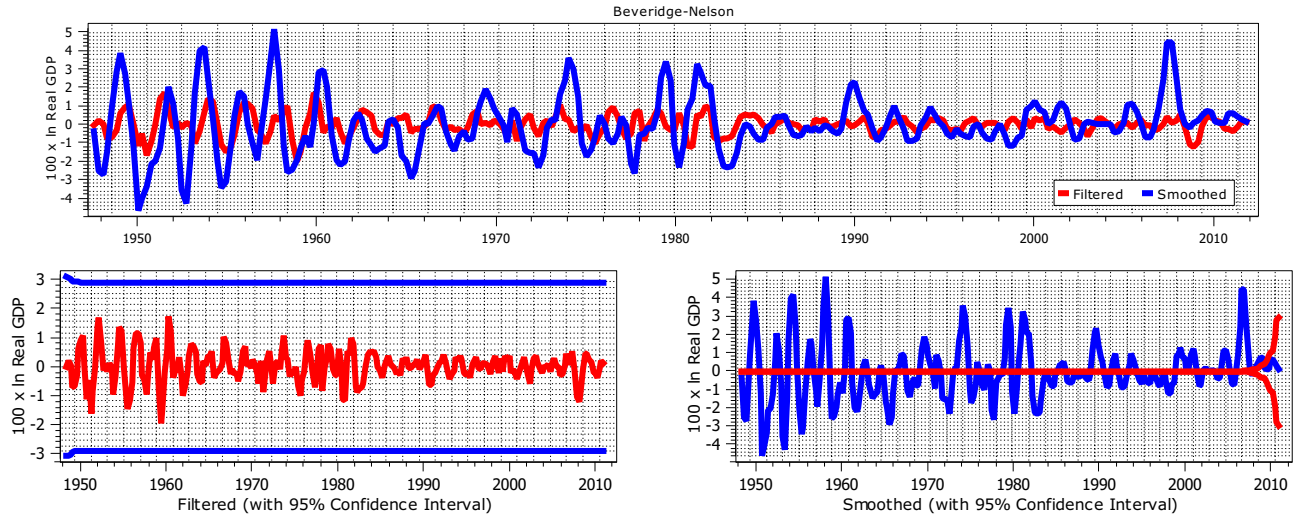
Figure 8: Smoothed and filtered estimates of the cycle for the SSE model
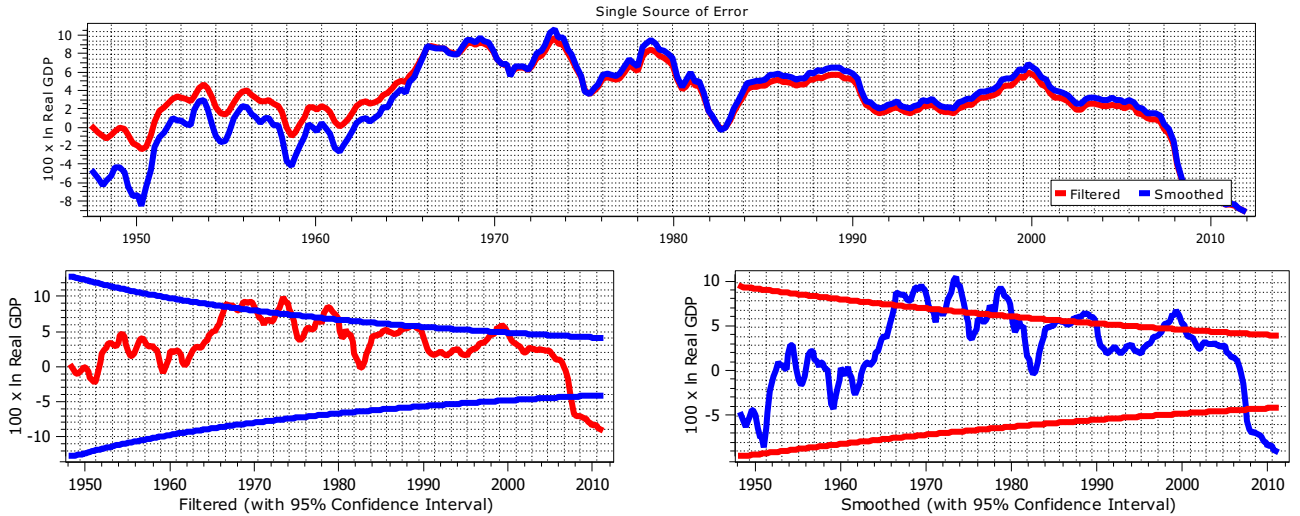


\section{Acknowledgements}

We would like to thank Denise Osborn, Graeme Wells and Ralph Snyder

for helpful discussions and suggestions. Versions of this paper were presented at the 32nd Annual International Symposium on Forecasting, Boston MA, a Conference in Honor of Charles Nelson, University of Washington, the Multivariate Time Series Modelling and Forecasting Workshop, Monash University, Melbourne, the Federal Reserve Bank of St. Louis Applied Time Series Econometrics Workshop, and various seminars. The present version benefited from the helpful comments of conference and seminar participants and the editor of this special issue, James Morley, and a referee. 


\section{References}

Anderson, Heather, Chian Nam Low, and Ralph Snyder (2006), "Single source of error state space approach to the Beveridge-Nelson decompoistion", Economics Letters, 91, 104-109.

Baxter, M. and R.G. King (1999), "Measuring business cycles: Approximate band-pass filters for economic time series", Review of Economics and Statistics, 81, 575-593.

Beveridge, Stephen and Charles R. Nelson (1981), "A new approach to decomposition of economic time series into permanent and ransitory components with particular attention to measurement of the 'business cycle"', Journal of Monetary Economics, 7, 151-174.

Christiano, L. and T.J. Fitzgerald (2003), "The band-pass filter", International Economic Review, 44, 435465.

Evans, George and Lucrezia Reichlin (1994), "Information, forecasts, and measurement of the business cycle", Journal of Monetary Economics, 233254.

Harvey, A.C. (1989), Forecasting, Structural Time Series Models and the Kalman Filter, Cambridge University Press, Cambridge.

Harvey, Andrew (2006), "Forecasting with unobserved time series models", in Graham Elliott, Clive W.J. Granger, and Allan Timmerman, editors, 
Handbook of Economic Forecasting, Volume 1, Elsevier, Amsterdam, New York, etc., chapter 7, 327-412.

Harvey, Andrew and Siem Jan Koopman (2000), "Signal extraction and the formulation of unobserved components models", Econometrics Journal, 3, $84-107$.

Jacobs, Jan P.A.M. (1998), Econometric Business Cycle Research, Kluwer Academic Publishers, Boston/Dordrecht/London.

Jacobs, Jan P.A.M. and Simon van Norden (2011), "Modeling data revisions: Measurement error and dynamics of "true" values", Journal of Econometrics, 161, 101-109.

Jun, Duk Bin, Sungho Park Dng Soo Kim, and Myoung Hwan Park (2012), "Parameter space restrictions in state space models", Journal of Forecasting, 31, 109-123.

Lee, J. and C.R. Nelson (2007), "Expectation horizon and the Phillips curve: the solution to an empirical puzzle", Journal of Applied Econometrics, 22, $161-178$.

Mills, Terence, C. (2003), Modelling Trends and Cycles in Economic Time Series, Palgrave Texts in Econometrics, Palgrave Macmillan, Houndmills, Basingstoke, Hampshire and New York.

Morley, James C. (2002), "A state-space approach to calculating the BeveridgeNelson decomposition", Economics Letters, 75, 123-127. 
Morley, James C. (2011), "The two interpretations of the Beveridge-Nelson decomposition", Macroeconomic Dynamics, 15, 419-439.

Morley, James C., Charles R. Nelson, and Eric Zivot (2003), "Why are the Beveridge-Nelson and unobserved-components decompositions of GDP so different?", The Review of Economics and Statistics, 85, 235-243.

Murray, C.J. and Charles R. Nelson (2004), "The great depression and output persistence: A reply to Papell and Prodan", Journal of Money, Credit and Banking, 36, 429-432.

Nelson, Charles (2008), "The Beveridge-Nelson decomposition in retrospect and prospect", Journal of Econometrics, 146, 202-206.

Oh, Kum Hwa, Eric Zivot, and Drew Creal (2008), "The relationship between the Beveridge-Nelson decomposition and other permanent-transitory decompositions that are popular in economics", Journal of Econometrics, 146, 207-219.

Perron, Pierre and Tatsuma Wada (2009), "Let's take a break: trends and cycle in US real GDP", Journal of Econometrics, 56, 749-765.

Proietti, Tomasso (2006), "Trend-cycle decompositions with correlated components", Econometric Reviews, 25, 61-84.

Sargent, T.J. (1989), "Two models of measurements and the investment accelator", The Journal of Political Economy, 97, 251-287. 
Sinclair, Tara M. (2009), "The relationships between permanent and transitory movements in U.S. output and the unemployment rate", Journal of Money, Credit and Banking, 41, 529-542.

Watson, Mark W. (1986), "Univiate detrending methods with stochastic trends", Journal of Monetary Economics, 18, 49-75.

Weber, Enzo (2011), "Analyzing U.S. output and the great moderation by simultaneous unobserved components", Journal of Money, Credit and Banking, 43, 1579-1597. 